\title{
Effects of Exogenous Salicylic Acid on Morphological and Biochemical Characteristics of Jatropha Curcas L. Irrigated with Saline Water
}

"Abo El-Soud, I.H. ${ }^{1}$ and Hokam, E.M. ${ }^{2}$

${ }^{1}$ Horticulture Departments, Fac. of Agric., Suez-Canal Univ., Ismailia, Egypt. 41522

${ }^{2}$ Soil and Water Departments, Fac. of Agric., Suez-Canal Univ., Ismailia, Egypt. 41522

*E-mail: Islamhassan2010@hotmail.com

Received on: $15 / 1 / 2017$

Accepted for publication on: 19/1/2017

\section{Abstract}

Salinity is one of the major rate-limiting to crop productivity. A field study was conducted at two developmental stages of Jatropha curcas L. namely: the juvenile stage (1-2 years) and the early mature stage (3-4 years). Three levels of water salinity were prepared by diluting sea water (Suez Canal water) to give 2.3, 4.7 and $7.0 \mathrm{dSm}^{-1}$, in addition to fresh water $\left(0.32 \mathrm{dSm}^{-1}\right)$. Jatropha plants were foliar sprayed with three levels of salicylic acid $(0.0,5.0$ and $10 \mathrm{mM})$. On the juvenile stage, the obtained results indicated that the most effective treatment for vegetative growth characters such as total leaf area (TLA); leaf relative water content $\left(\mathrm{RWC}_{\mathrm{L}}\right)$; relative growth rate (RGR) and leaf dry weight (LDW) was performed when Jatropha plants were irrigated with fresh water, without significant difference, than that irrigated plants with either 2.3 or $4.7 \mathrm{dSm}^{-1}$. Application of $5.0 \mathrm{mM}$ salicylic acid (SA) increased RGR, TLA and LDW for plants irrigated with saline water at $4.7 \mathrm{dSm}^{-1}$ as compared to either $0.0 \mathrm{mM}$ or $10 \mathrm{~m} \mathrm{M} \mathrm{SA}$.

On the early mature stage, application of $5.0 \mathrm{mM}$ SA had a positive effect on both vegetative characters and seed yield for $4.7 \mathrm{dSm}^{-1}$ salinity treatments as compared to control treatment. On the other hand, values of $\mathrm{RWC}_{\mathrm{L}}$ indicated that there was no water deficit in leaves of treatments irrigated with saline water or control. This indicates that application of SA-may minimize salinity stress. Foliar application of SA effectively increased chlorophyll. Generally, spraying jatropha shrubs with SA had a positive effect in reducing the negative impact of water salinity.

Keywords: Jatropha curcas; physic nut; physic nut oil; Salicylic Acid; sea water, irrigation; biofuel plant.

\section{Introduction}

The desert in Egypt occupies $94 \%$ of total area. A small number of crops can be cultivated in the deserts. Salt stresses either in soils or irrigation water are the major abiotic stresses that limit crop production in deserts (Allakhverdiev et al., 2000). Salt stress alters many different physiological and biochemical responses in plants, thereby affecting almost all plant processes (Iqbal et al., 2006). The important effects of salinity are reductions in plant growth parameters, such as decreased leaf area, leaf length and root and shoot dry weight (Saleh, 2012). Besides, irrigation with high-quality water has become along beggarly in many areas (Niu et. al., 2012).

Salicylic acid (SA) has been shown as an important signal molecule for modulating plant responses to abiotic stresses (Khan et al., 2015). The effects of SA on plant physiological processes varies depending on 
species, developmental stage, SA concentration and the environmental conditions (Shraiy and Hegazi, 2009).The positive effects of SA have been documented in inducing salinity tolerance of several crops (Khan et al., 2015). Data obtained by Najafian et al., (2009) showed that plants treated-with SA under salt stress had greater shoot and root dry weights, as well as SA increased photosynthetic rate and nutrient uptake.

The demand for biofuel has been rapidly growing in the last decade, global production of biofuel more than doubled (Licht, 2009). The potential resources for secondgeneration for biofuels production are Jatropha and algae. On the other hand, water scarcity is one of the major constraints of future potential production of second generation of biofuels (Hoekstra and Chapagain 2007). It is important for the development countries "such as Egypt" to start production of biodiesel to achieve the objectives of emission standards, and benefit from degraded lands and encourage the growth of the renewable energy industry (Croker, 2013).

Jatropha curcas (family Euphorbiaceae), a deciduous shrub, can be grown in semi-arid conditions, and marginal soils without large invest- ments in inputs (Jongschaap et al., 2007). Jatropha is commonly used for several purposes such as a natural hedge or fence-row, oil for soap production and cosmetics. Various parts of the plant have medicinal value; and can be used as an organic "green manure" fertilizer (Jewitt et al., 2009). About Five million hectares of Jatropha crop are being established on a worldwide scale, scattered across a vast number of countries. On the other hand, 700 feddan is now cultivated in Egypt, in Ismailia, Suez, Luxor and Giza governorates. The objective of this study was to investigate the effects of foliar spraying $J$. Curcas L. plants with salicylic acid on growth and oil yield under irrigation with saline water.

\section{Materials and Methods}

A field study was conducted at the Horticulture farm, Suez-Canal Univ., Ismailia, Egypt, from 2012 to 2015 on sandy soil (Table 1). This study has been carried out at two stages of growth of Jatropha plants. The first is the juvenile stage from transplanting to the end of the second year (without bearing fruits). Meanwhile, the second is the early stage of maturity up to the fourth year where plants begin to produce fruits.

Table 1. Some physical and chemical properties of soil

\begin{tabular}{|c|c|c|c|c|c|c|c|c|}
\hline \multicolumn{8}{|c|}{ Physical properties } \\
Coarse sand & Fine sand & Silt & Clay & Texture class & \multicolumn{2}{c|}{ Field capacity } \\
\hline $81.0 \%$ & $15.3 \%$ & $0.9 \%$ & $2.8 \%$ & \multicolumn{2}{c|}{ Sandy } & $0.13 \mathrm{~cm}^{3} \mathrm{~cm}^{-3}$ \\
\hline $\begin{array}{c}\text { Chemical properties } \\
\text { Electrical conductivity, } \\
\mathrm{dS} \mathrm{m} \mathrm{m}^{-1}\end{array}$ & $\begin{array}{c}\text { Organic matter } \\
\%\end{array}$ & $\begin{array}{c}\mathbf{N}_{\text {total }} \\
\%\end{array}$ & $\begin{array}{c}\mathbf{P} \\
\%\end{array}$ & $\begin{array}{c}\mathbf{K} \\
\%\end{array}$ & $\begin{array}{c}\mathbf{C a} \\
\mathrm{ppm}\end{array}$ & $\begin{array}{c}\mathbf{N a} \\
\mathrm{ppm}\end{array}$ & $\mathbf{C l ~ p p m}$ \\
\hline 0.98 & 0.39 & 0.25 & .008 & 0.03 & 88 & 107.3 & 211.7 \\
\hline
\end{tabular}


Jatropha seeds were planted directly into the field in Mid of October, 2011 at $2.5 \mathrm{~m} \mathrm{x} 2.5 \mathrm{~m}$. Three levels of irrigation water salinity based on water electric conductivity (EC), were prepared by diluting sea water (from Suez Canal) to gave 2.3, 4.7 and $7.0 \mathrm{dSm}^{-1}$, in addition to the fresh water as control $\left(0.32 \mathrm{dSm}^{-1}\right)$. Chemical analysis of diluted sea water used in irrigation is presented in Table (2). In Mid March (2012), Jatropha seedlings were foliar sprayed with three levels of SA as 0.0, 5.0 and $10 \mathrm{mM}$. SA was dissolved in small volume of ethanol and the solution was completed with water then Tween 20 was added to decrease the surface tension of the solution.

Plants sprayed with SA at four weeks interval, making six applications during the growth season. Plants were regular fertilized with complete fertilizers at the ratio of $6: 10: 6$ and micronutrients. Fertilizers were applied every 2 weeks for 20 times.

Table 2. Chemical properties of the irrigation waters

\begin{tabular}{|c|c|c|c|c|c|c|c|c|c|c|}
\hline \multirow{2}{*}{ Parameters } & \multirow{2}{*}{$\begin{array}{c}\text { EC, } \\
\text { dS m }^{-1}\end{array}$} & \multirow{2}{*}{ pH } & \multicolumn{4}{|c|}{ Soluble cations, meq $1^{-1}$} & \multicolumn{4}{|c|}{ Soluble anions, meq $1^{-1}$} \\
\hline & & & $\mathrm{Ca}^{2+}$ & $\mathrm{Mg}^{2+}$ & $\mathrm{Na}^{+}$ & $\mathbf{K}^{+}$ & $\mathrm{Cl}^{-}$ & $\mathrm{HCO}_{3}^{-}$ & $\mathrm{SO}_{4}{ }^{2-}$ & $\mathbf{S A R}^{* * * *}$ \\
\hline 11 & 0.32 & 7.95 & 0.97 & 0.60 & 1.64 & 0.39 & 1.50 & 1.30 & 0.80 & 1.85 \\
\hline Diluted sea water* & 7.00 & 7.67 & 6.00 & 9.00 & 57.5 & 1.50 & 49.0 & 3.40 & 21.6 & 21.0 \\
\hline
\end{tabular}

*Sea water: Nile water(1:10) $\quad$ **SAR: Sodium adsorption ratio

Relative growth rate (RGR), was calculated according to Antúnez (2001); total leaf area (TLA) according to Pérez-Harguindeguy et al., (2013); leaf dry weight (LDW), and seed yield plant-1. Concerning seed oil percentage, mature fruits were collected and air dried at room temperature. Then the seeds were crushed, and oil was extracted by hexane according to the method described in Bilal et al., (2013). Relative water content (leaves) RWCL was calculated according to the method described by Villar-Salvador et al., (2012). Total chlorophyll was determined and calculated according to the method described by Shibghatallah et al., (2013).

At the end of the experiment during August, samples were taken from third leaf from the plant apex, cleaned with distillated water, dried at $70^{\circ} \mathrm{C}$ to constant weight and finally grind to determine $\mathrm{N}, \mathrm{P}$ and $\mathrm{K}$ content. Total nitrogen percentage, was determined by micro-Kjeldahl according to the method described by Jones (2001). Phosphorus percentage was estimated calorimetrically as described by Mazumder and Majumdar (2003). Potassium and sodium percentages were determined using the flame photometer according to Jones (2001).

\section{Statistical Analyses:}

In a factorial experiment, treatments were performed in a randomized complete blocks design with three replications and three plants in each replicate. Data were subjected to ANOVA using General Linear Model. Means of the interaction effects were compared using Duncan at $5 \%$ level of probability. Data were analyzed by SPSS program. 


\section{Results and Discussions}

After 4 years of treatments (about 1450 days), the salinity induced modulations of growth were assessed by analyzing RGR for plant height, total leaf area and dry biomass of leaves (Tables 3 and 5). Concerning the main effect of salinity, there was no significant changes in RGR for plant height between control and $2.3 \mathrm{dSm}^{-1}$ and $4.7 \mathrm{dSm}^{-1}$ treated plants, respectively. The total leaf area was decreased significantly by $70.05 \%$ at $4.7 \mathrm{dSm}^{-1}$ compared to control (Table 5). The same conclusions were reported by Maggio et al., (2000) who found that salinity effects on ion accumulation have been reported in Salvadora persica plants treated with salinity up to $200 \mathrm{mM}$ $\mathrm{NaCl}$.

Table (3) shows that most of the vegetative characters (Total leaf area (TLA); Relative water content of leaves $\left(\mathrm{RWC}_{\mathrm{L}}\right) \quad$ Height-Relative growth rate (height -RGR); leaf dry weight (LDW) were significantly affected by interaction between SA concentrations and water salinity in both years. Results indicated that the most effective treatment was found when Jatropha was irrigated with the first level of salinity as $2.3 \mathrm{dSm}^{-1}$ and sprayed with $5.0 \mathrm{mM} \mathrm{SA}$, but without significant differences with treatments irrigated with either 0.32 or $4.70 \mathrm{dSm}^{1}$.

Generally, spraying plants with $5.0 \mathrm{mM}$ SA positively affected the growth characters at salinity level of $4.7 \mathrm{dSm}^{-1}$ compared with either 10.0 $\mathrm{mM}$ or without SA. Similar results were obtained by Dagar et al., (2006) and Kotoky et al., (2015). At the same effort, Fujimaki and Kikuchi (2010) reported that Jatropha is not more tolerance to salinity compared to other major crops such as soybean or wheat. According to Niu et al., (2012) salinity stress and deficit irrigation significantly reduced the growth and leaf development of greenhouse grown Jatropha plants. They added that the degree of the foliar salt damage was increased with increasing the salinity of irrigation water.

It is evident from Table (3) that the RWC of Jatropha was affected by salicylic acid and salinity and their interactions. Concerning the main effect of salinity, regardless salicylic acid, the largest increase in RWC was recorded in the treatment irrigated with $7.0 \mathrm{dSm}^{-1}$ salinity. Meanwhile, in the case of spraying salicylic acid, regardless to the effect of salinity, spraying plants with $5.0 \mathrm{mM}$ salicylic acid or without spraying salicylic acid, showed higher values of RWC without significant difference between them. RWC in leaves was $77.9 \%$ and $77.2 \%$ in control treatment while it was $86.3 \%$ and $88.4 \%$ in plants irrigated with $7.0 \mathrm{dSm}^{-1}$ in the first and second years, respectively (Table 3). 
Table 3. Main and interactions effects of water salinity levels and SA concentrations on vegetative growth characters of Jatropha at juvenile stage $\left(1^{\text {st }}\right.$ and $2^{\text {nd }}$ years).

\begin{tabular}{|c|c|c|c|c|c|c|c|c|c|}
\hline \multirow[t]{2}{*}{$\begin{array}{c}\text { EC } \\
\mathrm{dSm}^{-1} \\
\end{array}$} & \multirow[t]{2}{*}{$\begin{array}{c}\mathrm{SA} \\
\mathrm{mM} \\
\end{array}$} & \multicolumn{2}{|c|}{$\begin{array}{l}\text { TLA } \\
\mathrm{cm}^{2}\end{array}$} & \multicolumn{2}{|c|}{$\begin{array}{c}\mathrm{RWC}_{\mathrm{L}} \\
\%\end{array}$} & \multicolumn{2}{|c|}{$\begin{array}{c}\text { Height } \\
\text { RGR cm month }^{-1}\end{array}$} & \multicolumn{2}{|c|}{$\begin{array}{l}\text { LDW } \\
\text { g plant }^{-1}\end{array}$} \\
\hline & & $1^{\text {st }}$ year & $2^{\text {nd }}$ year & $1^{\text {st }}$ year & $2^{\text {nd }}$ year & $1^{\text {st }}$ year & $2^{\text {nd }}$ year & $1^{\text {st }}$ year & $2^{\text {nd }}$ year \\
\hline & & \multicolumn{8}{|c|}{ Main effects of water salinity } \\
\hline 0.32 & & $135.7^{\mathrm{a}}$ & $329.6^{b}$ & $77.9^{b}$ & $77.2^{\mathrm{b}}$ & $1.4^{\mathrm{a}}$ & $0.41^{\mathrm{b}}$ & $0.38^{\mathrm{d}}$ & $0.97^{\mathrm{c}}$ \\
\hline 2.3 & & $126.4^{\mathrm{a}}$ & $378.8^{\mathrm{a}}$ & $76.8^{\mathrm{b}}$ & $77.2^{\mathrm{b}}$ & $1.4^{\mathrm{a}}$ & $0.41^{\mathrm{b}}$ & $0.57^{\mathrm{b}}$ & $1.8^{\mathrm{a}}$ \\
\hline 4.7 & & $126.4^{\mathrm{a}}$ & $340.1^{\mathrm{b}}$ & $81.2^{\mathrm{ab}}$ & $80.5^{\mathrm{b}}$ & $1.4^{\mathrm{a}}$ & $0.49^{\mathrm{a}}$ & $0.68^{\mathrm{a}}$ & $1.7^{\mathrm{a}}$ \\
\hline \multirow[t]{5}{*}{7.0} & & $115.7^{\mathrm{b}}$ & $284.1^{\mathrm{bc}}$ & $86.3^{\mathrm{a}}$ & $88.4^{\mathrm{a}}$ & $1,4^{\mathrm{a}}$ & $0.26^{\mathrm{c}}$ & $0.51^{\mathrm{c}}$ & $1.40^{\mathrm{b}}$ \\
\hline & & \multicolumn{8}{|c|}{ Main effects of SA concentrations } \\
\hline & 0 & $112.4^{\mathrm{c}}$ & $377.5^{b}$ & $82.8^{\mathrm{a}}$ & $84.0^{\mathrm{a}}$ & $1.3^{\mathrm{b}}$ & $0.36^{\mathrm{c}}$ & $0.40^{\mathrm{b}}$ & $1.55^{\mathrm{a}}$ \\
\hline & 5 & $143.2^{\mathrm{a}}$ & $409.5^{\mathrm{a}}$ & $81.5^{\mathrm{a}}$ & $81.9^{\mathrm{ab}}$ & $1.4^{\mathrm{ab}}$ & $0.42^{\mathrm{a}}$ & $0.59^{\mathrm{a}}$ & $1.56^{\mathrm{a}}$ \\
\hline & 10 & $122.6^{\mathrm{b}}$ & $212.5^{\mathrm{c}}$ & $77.4^{\mathrm{a}}$ & $76.7^{\mathrm{b}}$ & $1.5^{\mathrm{a}}$ & $0.39^{\mathrm{b}}$ & $0.55^{\mathrm{a}}$ & $1.32^{\mathrm{b}}$ \\
\hline & & \multicolumn{8}{|c|}{ Interaction effects of water salinity and $\mathrm{SA}$ concentrations } \\
\hline \multirow{4}{*}{0.32} & 0 & $104.0^{\mathrm{e}}$ & $437.2^{\mathrm{a}}$ & $85.1^{\mathrm{ab}}$ & $85.5^{\mathrm{ab}}$ & $1.14^{\mathrm{d}}$ & $0.47^{\mathrm{c}}$ & $0.43^{\mathrm{e}}$ & $1.79^{\mathrm{c}}$ \\
\hline & 5 & $185.6^{\mathrm{a}}$ & $360.8^{\mathrm{b}}$ & $77.02^{\mathrm{abc}}$ & $76.4^{\mathrm{bc}}$ & $1.58^{\mathrm{a}}$ & $0.38^{\mathrm{de}}$ & $0.31^{\mathrm{f}}$ & $0.61^{\mathrm{f}}$ \\
\hline & 10 & $117.6^{\text {cde }}$ & $190.8^{\mathrm{e}}$ & $71.7^{\mathrm{c}}$ & $69.8^{c}$ & $1.42^{\mathrm{ab}}$ & $0.38^{\mathrm{de}}$ & $0.39^{\mathrm{e}}$ & $0.52^{\mathrm{f}}$ \\
\hline & 0 & $128.0^{\mathrm{bcd}}$ & $448.7^{\mathrm{a}}$ & $83.26^{\mathrm{abc}}$ & $85.5^{\mathrm{ab}}$ & $1.5^{8 \mathrm{a}}$ & $0.43^{\mathrm{cd}}$ & $0.41^{\mathrm{e}}$ & $1.48^{\mathrm{d}}$ \\
\hline \multirow[t]{3}{*}{2.3} & 5 & $136.0^{\mathrm{bc}}$ & $477.7^{\mathrm{a}}$ & $75.34^{\mathrm{bc}}$ & $76.4^{\mathrm{bc}}$ & $1.06^{\mathrm{d}}$ & $0.45^{\mathrm{c}}$ & $0.72^{b}$ & $2.10^{\mathrm{ab}}$ \\
\hline & 10 & $115.2^{\mathrm{de}}$ & $210.0^{\mathrm{e}}$ & $71.88^{c}$ & $69.8^{c}$ & $1.56^{\mathrm{ab}}$ & $0.33^{\mathrm{ef}}$ & $0.58^{\mathrm{cd}}$ & $1.70^{\mathrm{c}}$ \\
\hline & 0 & $105.6^{\mathrm{e}}$ & $300.7^{\mathrm{cd}}$ & $81.23^{\mathrm{abc}}$ & $80.3^{\mathrm{abc}}$ & $1.17^{\mathrm{cd}}$ & $0.31^{\mathrm{f}}$ & $0.40^{\mathrm{e}}$ & $1.15^{\mathrm{e}}$ \\
\hline \multirow[t]{3}{*}{4.7} & 5 & $145.6^{\mathrm{b}}$ & $450.5^{\mathrm{a}}$ & $84.49^{\mathrm{ab}}$ & $84.5^{\mathrm{ab}}$ & $1.36^{\mathrm{bc}}$ & $0.61^{\mathrm{a}}$ & $0.93^{\mathrm{a}}$ & $2.27^{\mathrm{a}}$ \\
\hline & 10 & $128.0^{\mathrm{bcd}}$ & $269.0^{\mathrm{d}}$ & $77.98^{\mathrm{abc}}$ & $76.7^{\mathrm{bc}}$ & $1.58 \mathrm{a}$ & $0.55^{\mathrm{b}}$ & $0.70^{\mathrm{b}}$ & $1.90^{\mathrm{bc}}$ \\
\hline & 0 & $112.0^{\mathrm{de}}$ & $323.3^{b c}$ & $81.65^{\mathrm{abc}}$ & $84.7^{\mathrm{ab}}$ & $1.36 \mathrm{bc}$ & $0.23^{\mathrm{h}}$ & $0.62^{\mathrm{c}}$ & $1.78^{\mathrm{c}}$ \\
\hline \multirow[t]{2}{*}{7.0} & 5 & $105.6^{\mathrm{e}}$ & $349.0^{\mathrm{bc}}$ & $89.06^{\mathrm{a}}$ & $90.3^{\mathrm{a}}$ & $1.53^{\mathrm{ab}}$ & $0.25^{\mathrm{gh}}$ & $0.38^{\mathrm{ef}}$ & $1.27^{\mathrm{de}}$ \\
\hline & 10 & $129.6^{\mathrm{bcd}}$ & $180.0^{\mathrm{e}}$ & $88.08^{\mathrm{a}}$ & $90.3^{\mathrm{a}}$ & $1.36^{\mathrm{bc}}$ & $0.29 \mathrm{f}^{\mathrm{g}}$ & $0.53^{\mathrm{d}}$ & $1.15^{\mathrm{e}}$ \\
\hline
\end{tabular}

Means followed by the same superscript letters are not significantly different at $\mathrm{P}<0.05$ according to Duncan's multiple test.

Data in the same Table (3) show that the interaction between irrigation with saline water and spraying plants with salicylic acid, had an impact on the water content of the leaves, expressed as RWC. The highest values were seen at treatment irrigated with $7.0 \mathrm{dSm}^{-1}$ and sprayed with 5.0 or $10.0 \mathrm{mM}$ salicylic acid without differences between them. Relative water content of a leaf is a measurement the of 'water deficit' in the leaf, and may indicate a degree of water stress. Changes in RWC are proportional to changes in turgor pressure of the leaf, and so becomes an indirect measure of the change in turgor pressure under salinity treatments.

We can point out that plant height-RGR reached a maximum during the first year and there declined during on the second year consistently as shown in Table (3). The decreasing value of height-RGR was due to greater contribution to leaf dry matter (LDW) or may be due to the spread of the roots, a similar finding was reported by Ismail, (1992) on Calotropis procera.

Nitrogen, phosphorus, potassium, sodium percentage and Total Chlorophyll in leaves $\left(2^{\text {nd }}\right.$ years $)$

Table (4) indicates that both of $\mathrm{N} \%$ and $\mathrm{K} \%$ were higher with 10.0 $\mathrm{mM}$ than 0 or $5.0 \mathrm{mM}$ SA under all levels of salinity. Phosphorus\% data indicated that the most effective treatment was found when Jatropha was sprayed with $10.0 \mathrm{mM}$ SA under irrigation with water of $4.7 \mathrm{dSm}^{-1}$. It is noted from Table (4) that sodium $\%$ in leaves under $5.0 \mathrm{mM}$ SA treat- 
ment was lower than that with 0 and $10 \mathrm{mM}$, under all levels of salinity. Abdi et al., (2011) found that plants sprayed with SA showed lowest amount of $\mathrm{Na}$ accumulation. One of tolerance mechanisms may be exclusion of $\mathrm{Na}+$ from the shoots by retaining it in root. Also, they suggested that alteration of mineral uptake from SA applications may be one of the mechanisms for alleviation of salt stress, and positively affected $\mathrm{K}+/ \mathrm{Na}+$ ratio. Similar explanation was reported by Parida et al., (2016). Also, War et al., (2011) concluded that SA plays an important role in induction of plant defensive system against a variety of biotic and abiotic stresses.

Concerning chlorophyll concentration, data indicated that the most effective treatment was found when Jatropha was irrigated with water of $4.7 \mathrm{dSm}^{-1}$, and sprayed with $5.0 \mathrm{mM}$ SA. As stress increases, chlorophyll content decreases faster than other pigments (Bannari et al., 2007). Jaleel et al., (2009) mentioned that the decrease of leaf chlorophyll content under high salinity might be a reason to the destruction of pigments and the instability of the pigmentprotein complex.

Table 4. Main and interactions effects of water salinity levels and SA concentrations on Nitrogen \%, Phosphorus\%, Potassium\%, sodium \% and Total Chlorophyll contents in leaves of Jatropha at early-growth stage $\left(2^{\text {nd }}\right.$ years $)$

\begin{tabular}{|c|c|c|c|c|c|c|}
\hline \multicolumn{2}{|c|}{ Treatments } & \multirow{2}{*}{$\begin{array}{l}\mathbf{N} \\
\%\end{array}$} & \multirow{2}{*}{$\begin{array}{l}\mathbf{P} \\
\%\end{array}$} & \multirow{2}{*}{$\begin{array}{l}\mathbf{K} \\
\%\end{array}$} & \multirow{2}{*}{$\begin{array}{c}\mathrm{Na} \\
\%\end{array}$} & \multirow{2}{*}{$\begin{array}{c}\text { Total Chloro- } \\
\text { phyll } \\
\text { mg g }^{-1}\end{array}$} \\
\hline $\begin{array}{c}E C \\
\left(\mathrm{dSm}^{-1}\right)\end{array}$ & $\begin{array}{c}\text { SA } \\
(\mathbf{m M})\end{array}$ & & & & & \\
\hline \multicolumn{7}{|c|}{ Main effects of water salinity } \\
\hline 0.32 & & $3.55^{b}$ & $0.20^{\mathrm{b}}$ & $1.05^{\mathrm{c}}$ & $0.38^{\mathrm{c}}$ & $0.26^{\mathrm{b}}$ \\
\hline 2.3 & & $3.45^{\mathrm{b}}$ & $0.19^{\mathrm{b}}$ & $1.80^{\mathrm{a}}$ & $1.10^{\mathrm{a}}$ & $0.27^{\mathrm{b}}$ \\
\hline 4.7 & & $3.95^{\mathrm{a}}$ & $0.35^{\mathrm{a}}$ & $1.40^{\mathrm{b}}$ & $1.00^{\mathrm{b}}$ & $0.47^{\mathrm{a}}$ \\
\hline 7.0 & & $3.43^{\mathrm{b}}$ & $0.21^{\mathrm{b}}$ & $0.88^{\mathrm{d}}$ & $1.07^{\mathrm{ab}}$ & $0.19^{c}$ \\
\hline & & \multicolumn{5}{|c|}{ Main effects of SA concentrations } \\
\hline & 0 & $3.14^{\mathrm{c}}$ & $0.25^{\mathrm{b}}$ & $0.87^{\mathrm{b}}$ & $0.95^{\mathrm{b}}$ & $0.20^{\mathrm{c}}$ \\
\hline & 5 & $3.61^{\mathrm{b}}$ & $0.19^{\mathrm{c}}$ & $0.87^{\mathrm{b}}$ & $0.66^{\mathrm{c}}$ & $0.43^{\mathrm{a}}$ \\
\hline & 10 & $4.04^{\mathrm{a}}$ & $0.28^{\mathrm{a}}$ & $2.07^{\mathrm{a}}$ & $1.06^{\mathrm{a}}$ & $0.26^{\mathrm{b}}$ \\
\hline & & \multicolumn{5}{|c|}{ Interaction effects of water salinity and $\mathrm{SA}$ concentrations } \\
\hline 0.32 & 0 & $3.36 b^{c}$ & $0.29^{\mathrm{c}}$ & $0.48^{\mathrm{e}}$ & $0.44^{\mathrm{f}}$ & $0.23^{\mathrm{de}}$ \\
\hline & 5 & $3.30^{\mathrm{c}}$ & $0.12^{\mathrm{g}}$ & $0.52^{\mathrm{e}}$ & $0.28^{\mathrm{g}}$ & $0.26^{\mathrm{cd}}$ \\
\hline & 10 & $4.00^{\mathrm{a}}$ & $0.20^{\mathrm{d}}$ & $2.16^{\mathrm{a}}$ & $0.42^{\mathrm{f}}$ & $0.30^{\mathrm{bc}}$ \\
\hline 2.3 & 0 & $2.80^{\mathrm{d}}$ & $0.15^{\mathrm{fg}}$ & $1.14^{\mathrm{d}}$ & $1.00^{\mathrm{bc}}$ & $0.19^{\mathrm{e}}$ \\
\hline & 5 & $3.36^{\mathrm{bc}}$ & $0.28 \mathrm{c}$ & $1.84^{\mathrm{b}}$ & $0.89^{\mathrm{cd}}$ & $0.29^{b c}$ \\
\hline & 10 & $4.20^{\mathrm{a}}$ & $0.15^{\mathrm{fg}}$ & $2.30^{\mathrm{a}}$ & $1.41^{\mathrm{a}}$ & $0.33^{b}$ \\
\hline 4.7 & 0 & $3.72^{\mathrm{abc}}$ & $0.33^{\mathrm{b}}$ & $1.22^{\mathrm{d}}$ & $0.98^{b c}$ & $0.21^{\mathrm{e}}$ \\
\hline & 5 & $3.92^{\mathrm{a}}$ & $0.19^{\mathrm{de}}$ & $0.62^{\mathrm{e}}$ & $0.76^{\mathrm{de}}$ & $0.89^{\mathrm{a}}$ \\
\hline & 10 & $4.21^{\mathrm{a}}$ & $0.56^{\mathrm{a}}$ & $2.31^{\mathrm{a}}$ & $1.31^{\mathrm{a}}$ & $0.31^{b c}$ \\
\hline 7.0 & 0 & $2.67^{\mathrm{d}}$ & $0.21^{\mathrm{d}}$ & $0.64^{\mathrm{e}}$ & $1.40^{\mathrm{a}}$ & $0.18^{\mathrm{e}}$ \\
\hline & 5 & $3.86^{\mathrm{ab}}$ & $0.16^{\mathrm{ef}}$ & $0.50^{\mathrm{e}}$ & $0.72^{\mathrm{e}}$ & $0.27^{\mathrm{cd}}$ \\
\hline & 10 & $3.75^{\mathrm{abc}}$ & $0.26^{\mathrm{c}}$ & $1.50^{\mathrm{c}}$ & $1.10^{\mathrm{b}}$ & $0.11^{\mathrm{f}}$ \\
\hline
\end{tabular}

Means followed by the same superscript letters are not significantly different at $\mathrm{P}<0.05$ according to Duncan's multiple test. 
Vegetative growth; seed yield and oil content (\%) on early mature stage $\left(4^{\text {th }}\right.$ year $)$

Effects of interaction between SA application and water salinity on some vegetative characters, TLA; RWC; RGR; LDW and seeds yield and oil content at early mature stage are listed in Table (5). Data shows that, the studied vegetative growth characters were significantly affected by interaction between SA concentrations and water salinity. The most effective treatments for growth characters were occurred when Jatropha shrubs were irrigated by saline water under level of $0.32 \mathrm{dSm}^{-1}$ (fresh water) but without significant difference with that irrigated with $4.7 \mathrm{dSm}^{-1}$ particularly, at $5.0 \mathrm{mM}$ SA. It's clear that, SA application at $5.0 \mathrm{mM}$ with either 0.32 or $4.7 \mathrm{dSm}^{-1}$ level increased fruit yield. These results are in agreement with those obtained on Jatropha by Hussein et al., 2013. Application of $5 \mathrm{mM}$ SA affected positively the growth characters at diluted sea water $\left(4.7 \mathrm{dSm}^{-1}\right)$ compared with
0 or $10.0 \mathrm{mM} \mathrm{SA}$. The positive effect of SA on growth parameters could be attributed to its bio-regulator effect on physiological and biochemical processes in plants (EL Tayeb, 2005). Values of RWC as a character used to assess water status in leaf tissues indicated that there was no water deficits between fresh irrigated and saltstressed leaves, which indicate that application of SA may lead to reduce salinity stress

In relation to oil \% of seeds, data indicated that, the most effective treatment was found when Jatropha was sprayed with $5.0 \mathrm{mM}$ SA and irrigated with 0.32 or $4.7 \mathrm{dSm}^{-1} 1$. In general, average oil recovery of $25 \%$ by weight from seeds of Jatropha plant cultivated in different places (Tewfik et al., 2012 and Pandey et al., 2012). The oil content of Jatropha seeds of the actual study was determined quantitatively to be $20 \%$ based on dry seed weight. The variation in oil quantity might be due to change in climatic agricultural conditions (Hawash et al., 2008).

Table 5. Main and interactions effects of water salinity levels and SA concentrations on some vegetative growth, seed yield and oil content $(\%)$ of Jatropha shrubs at early mature stage $\left(4^{\text {th }}\right.$ years $)$.

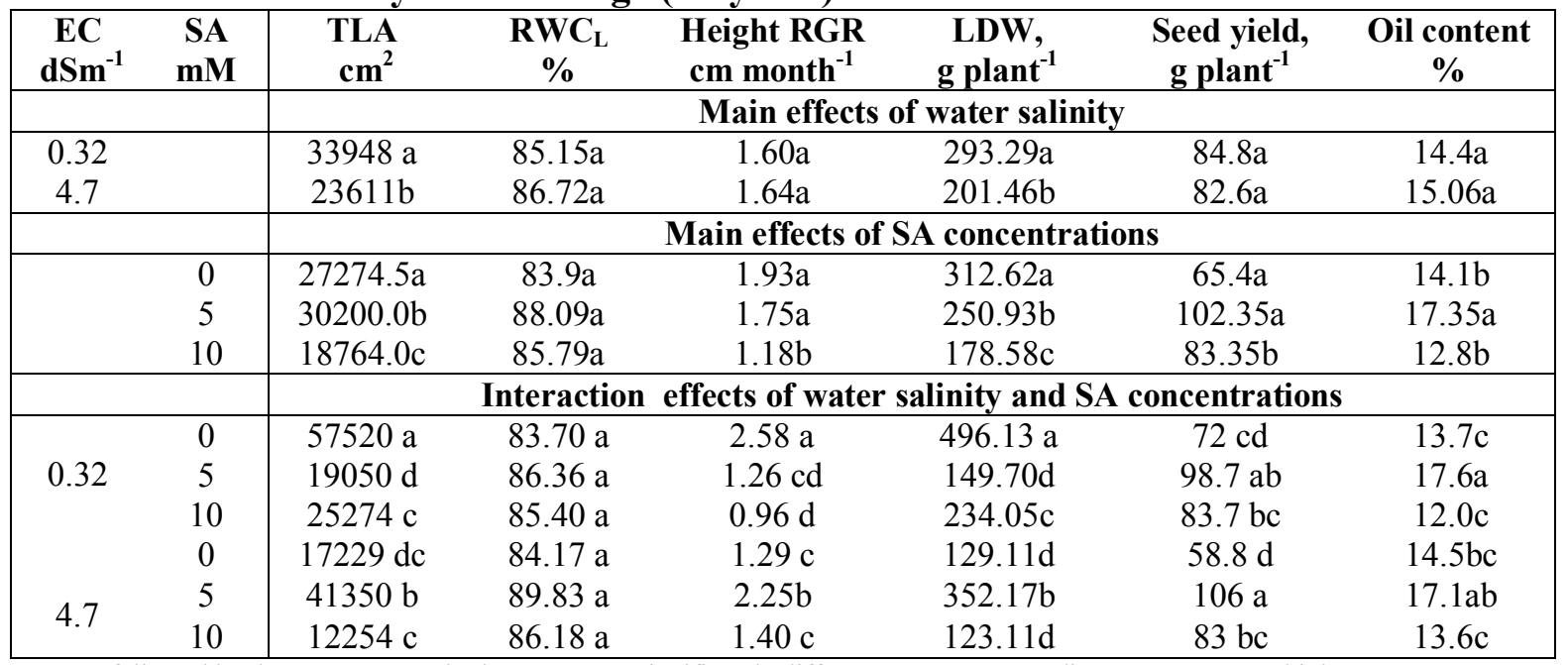

Means followed by the same superscript letters are not significantly different at $\mathrm{P}<0.05$ according to Duncan's multiple test. 
Nitrogen, phosphorus, potassium, sodium percentage and Total Chlorophyll in leaves $\left(4^{\text {th }}\right.$ year $)$ :

Data in Table (6) show that Nitrogen percentage with $10.0 \mathrm{mM}$ SA treatments was higher than 0 or 5.0 $\mathrm{mM}$ SA under water salinity of 4.7 dSm-1, but Potassium percentage with $10.0 \mathrm{SA} \mathrm{mM}$ treatments was higher than 0 or $5 \mathrm{mM}$ SA under all levels of water salinity. Data of Phosphorus percentage indicated that, the most effective treatment was found when Jatropha irrigated under water of $0.32 \mathrm{dSm}^{-1}$, without addition of SA, while Sodium percentage with $5.0 \mathrm{mM}$ SA treatment was lower than that with 0 and $10.0 \mathrm{mM}$, under 4.7 $\mathrm{dSm}^{-1} 1$ water salinity. In relation to total chlorophyll, data indicate that, the most effective treatment was found when Jatropha was sprayed with $5.0 \mathrm{mM} \mathrm{SA}$, under low levels of water salinity.

Table 6. Main and interactions effects of water salinity levels and SA concentrations on Nitrogen\%, Phosphorus\%, Potassium\%, sodium \% and Total Chlorophyll content on leaves of Jatropha at early-mature stage (4th year)

\begin{tabular}{|c|c|c|c|c|c|c|}
\hline $\begin{array}{c}\mathrm{EC}, \\
\mathrm{dSm}^{-1}\end{array}$ & $\begin{array}{l}\text { SA } \\
\text { mM }\end{array}$ & $\begin{array}{l}\mathbf{N} \\
\%\end{array}$ & $\begin{array}{l}\mathbf{P} \\
\%\end{array}$ & $\begin{array}{l}\mathbf{K} \\
\%\end{array}$ & $\begin{array}{l}\mathrm{Na} \\
\%\end{array}$ & $\begin{array}{l}\text { Total Chlorophyll } \\
\text { mg g }^{-1}\end{array}$ \\
\hline & & \multicolumn{5}{|c|}{ Main effects of water salinity } \\
\hline \multirow{6}{*}{$\begin{array}{c}0.32 \\
4.7\end{array}$} & & $3.10^{\mathrm{a}}$ & $0.27^{\mathrm{a}}$ & $0.72^{\mathrm{a}}$ & $0.46^{\mathrm{a}}$ & $0.32^{\mathrm{a}}$ \\
\hline & & $3.35^{\mathrm{a}}$ & $0.07^{\mathrm{b}}$ & $0.46^{\mathrm{b}}$ & $0.97^{\mathrm{a}}$ & $0.35^{\mathrm{a}}$ \\
\hline & & \multicolumn{5}{|c|}{ Main effects of SA concentrations } \\
\hline & 0 & $2.99^{b}$ & $0.16^{\mathrm{a}}$ & $0.52^{\mathrm{b}}$ & $0.6^{\mathrm{b}}$ & $0.29^{\mathrm{b}}$ \\
\hline & 5 & $3.31^{\mathrm{ab}}$ & $0.1^{\mathrm{b}}$ & $0.38^{\mathrm{c}}$ & $0.7^{\mathrm{b}}$ & $0.38^{\mathrm{a}}$ \\
\hline & 10 & $3.39^{\mathrm{a}}$ & $0.09^{\mathrm{b}}$ & $0.87^{\mathrm{a}}$ & $0.8^{\mathrm{a}}$ & $0.35^{\mathrm{a}}$ \\
\hline & & \multicolumn{5}{|c|}{ Interaction effects of water salinity and SA concentrations } \\
\hline \multirow{4}{*}{0.32} & 0 & $2.97^{b}$ & $0.278^{\mathrm{a}}$ & $0.50^{\mathrm{c}}$ & $0.40^{\mathrm{d}}$ & $0.30^{b}$ \\
\hline & 5 & $3.25^{\mathrm{ab}}$ & $0.08^{c}$ & $0.66^{\mathrm{b}}$ & $0.52^{\mathrm{c}}$ & $0.37^{\mathrm{a}}$ \\
\hline & 10 & $3.08^{\mathrm{b}}$ & $0.126^{\mathrm{b}}$ & $1.00^{\mathrm{a}}$ & $0.46^{\mathrm{cd}}$ & $0.31^{\mathrm{b}}$ \\
\hline & 0 & $3.02^{\mathrm{b}}$ & $0.045^{\mathrm{d}}$ & $0.53^{\mathrm{c}}$ & $0.91^{\mathrm{b}}$ & $0.29^{b}$ \\
\hline \multirow{2}{*}{4.7} & 5 & $3.36^{\mathrm{ab}}$ & $0.121^{\mathrm{b}}$ & $0.11^{\mathrm{d}}$ & $0.88^{\mathrm{b}}$ & $0.38^{\mathrm{a}}$ \\
\hline & 10 & $3.69^{\mathrm{a}}$ & $0.07^{\mathrm{c}}$ & $0.74^{\mathrm{b}}$ & $1.14^{\mathrm{a}}$ & $0.39^{\mathrm{a}}$ \\
\hline
\end{tabular}

Means followed by the same superscript letters are not significantly different at $\mathrm{P}<0.05$ according to Duncan's multiple test.

In spite of higher accumulation of sodium in leaf tissue with increasing salinity (Tables 4 and 6), the RWC of leaf did not declined but it was increased due to high salinity. This artifact provide an indirect indication that $\mathrm{Na}^{+}$is effectively compartmentalized in the vacuoles and this is required for osmotic adjustment, so it can be tacitly assumed that water relations and the ability to adjust the osmotic concentration play a vital role in overall growth and development of plants. In summary, results suggest that Jatropha can tolerate salinity by maintaining osmotic balance and ion homeostasis. Same conclusion was recorded by Parida et al., (2016).

\section{Values of soil salinity}

Soil salinity at the end of study for both studied stages: (the end of second year and immediately after fruits collecting), the EC in soil was measured and listed in Table (7). Data indicate that, the higher water salinity in irrigation water Leads to the higher residual soil salinity. So, each plant area was periodically leached dependent on the growth stage as described by (Hokam and Abo El-Soud, 2016). 
Table 7. Values of soil salinity (Electrical conductivity) for early-growth and early mature stages

\begin{tabular}{|c|c|c|c|c|}
\hline \multicolumn{5}{|c|}{ juvenile stage } \\
\hline $\mathrm{EC}_{\text {soil }}$ & $7.0 \mathrm{dSm}^{-1}$ & $4.7 \mathrm{dSm}^{-1}$ & $2.3 \mathrm{dSm}^{-1}$ & $0.32 \mathrm{dSm}^{-1}$ \\
\hline & 7.64 & 5.11 & 2.61 & 0.96 \\
\hline \multicolumn{5}{|c|}{ Early mature stage } \\
\hline $\mathrm{EC}_{\text {soil }}$ & -- & $4.7 \mathrm{dSm}^{-1}$ & -- & $0.32 \mathrm{dSm}^{-1}$ \\
\hline & & 6.0 & & 2.7 \\
\hline
\end{tabular}

\section{Conclusion}

To avoid the competition with food production, marginal land and poor quality water must be targeted for producing bioenergy crops... SA application of $5 \mathrm{mM}$ was positively affected vegetative growth characters, particularly at $4.7 \mathrm{dSm}^{-1} 1$ salinity level. In mature stage, values of leaf relative water content character indicated that water deficits in leaf tissues did not exist between fresh irrigated and salt-stressed plants. The most potential vegetative growth and seed yield at mature stage were performed under treatment with fresh water compared to that of 7.2 or $4.7 \mathrm{dSm}^{-1}$. Application of $5.0 \mathrm{mM}$ SA had a positive effect on both vegetative growth and capsule yield for $4.7 \mathrm{dSm}^{-1} 1$ salinity treatment, compared to those for fresh water. It is recommended to interest with breeding for this shrub so can be overcome confusion and mystery resulting from genetic variation because original of plant still by seed.

\section{References}

Abdi, G.; Mohammadi, M. and Hedayat, M. (2011). Effect of salicylic acid on $\mathrm{Na}+$ accumulation in shoot and roots of tomato in different $\mathrm{K}+$ status. J. Biol. Environ. Sci., 5(13): 31-35.

Allakhverdiev, S.I.; Sakamoto, A.; Nishiyama, Y.; Inaba, M. and Murata N. (2000). Ionic and Osmotic Effects of NaCl-Induced Inactiva- tion of Photosystems I and II in Synechococcus sp. Plant Physiology. 123(3):1047-1056.

Antúnez, I. (2001). Relative growth rate in phylogenetically related deciduous and evergreen woody species. - Oecologia 128: 172-180.

Bannari, A. Khurshid, K. S.; Staenz, K. and Schwarz, J.W. (2007). A comparison of hyperspectral chlorophyll indices for wheat crop chlorophyll content estimation using laboratory reflectance measurements. IEEE Trans. Geosci. Remote Sensing, 45:3063-3074.

Bilal, S.; Mohammed-Dabo, I. A; Nuhu, M.; Kasim, S. A.; Almustapha I. H. and Yamusa Y. A. (2013). Production of biolubricant from Jatropha curcas seed oil. Journal of Chemical Engineering and Materials Science. 4: 72-79.

Croker, A. (2013). Renewable Energy in Egypt: Hydro, Solar and Wind. Norton Rose Fulbright. http://www.nortonrosefulbright.co $\mathrm{m} /$ knowledge/publications/74735/r enewable-energy-in-egypt.

Dagar, J.C.; Tomar, O.S.; Kumar, Y. Bhagwan, H. Yadav, R.K. and Tyagi, N.K. (2006). Performance of some under-explored crops under saline irrigation in semiarid climate in Northwest India. Land Degradation \& Development 17: 285-299.

El Tayeb, M. A. (2005). Response of barley grains to the interactive effect of salinity and salicylic acid. Plant Growth Regu., 45: 215-224. 
Fujimaki, H. and Kikuchi N.N (2010). Drought and salinity tolerances of young Jatropha. Int. grophysics 24 : 121-127.

Hawash, S.; Kamal, N. and El Diwani, G. (2008). Egyptian Jatropha Oil Extraction for Biodiesel production. AFINIDAD 15: 470 - 474.

Hoekstra, A.Y. and Chapagain. A.K. (2007). Water footprints of nations: water use by people as a function of their consumption pattern. Water Resource Manage. 21, 35-48.

Hokam, E. M. and Abo El-soud, I. H. (2016). Evaluation of Growth Parameters for Jatropha curcas L. (Biofuel Plant) under Salinity and Water Stress Using Tensiometer for Irrigation Guiding. Egyptian Journal of Soil Science, 56: In press.

Hussein, M.M.; El-Ashry, K. and ElFaham, S. Y. (2013). Effect of Salinity and MKP on Growth and Mineral Status of Jatropha Plants Journal of Applied Sciences Research, 9 (7): 4193-4203.

Iqbal, M.; Ashraf, M. and Jamil, A. (2006). Seed enhancement with cytokinins: changes in growth and grain yield in salt stressed wheat plants. Plant Growth Regul. 50: 29-39.

Ismail, A.M.A. (1992). Physiological Growth Analysis of the LifeHistory of Calotropis procera (Alt.) Alt. F. Qatar Univ. Sci. J. 12: 94- 100.

Jaleel CA, Sankar B, Sridharan R, Panneerselvam R (2009). Soil salinity alters growth, chlorophyll content, and secondary metabolite accumulation in Catharanthus roseus. Turk J Biol 32(2): 79-83.

Jewitt, G.P.W.; Wen, H.W.; Kunz, R.P. and Van Rooyen, A.M., (2009). Scoping Study on Water Use of Crops/Trees for Biofuels in
South Africa. Report to the Water Research Commission, Wrc Report No. 1772/1/09 (ISBN 978-177005-884-2).

Jones, Jr. J.B. (2001). Laboratory Guide for Conducting Soil Tests and Plant Analysis. CRC Press, Washington, DC., USA., ISBN-13: 9781420025293, p: 384.

Jongschaap, R. E.; Corre, P. S. Bindraban, C. P. S. and Brandenburg, W.A. (2007). Claims and Facts on Jatropha curcas L. Report 158, Plant Research International, Wageningen.

Khan, M.; Fatma. M.; Per, T.S.; Anjum, N.A. and Khan, N.A. (2015). Salicylic acid-induced abiotic stress tolerance and underlying mechanisms in plants. Front Plant Sci. 6: 462-468.

Khan, M.R; Mehar, F.; Tasir S. P.; Anjum, N.A. and N. A. Khan (2015). Salicylic acid-induced abiotic stress tolerance and underlying mechanisms in plants. Front Plant Sci. 6: 462-469.

Kotoky, R. A.; Rabha, A.; Gogoi, A.; Nath S. C. and Saikia, S. P. (2015). Correlation studies in seed traits, moisture and oil content and effect of hormones on flowering of Jatropha curcas L. Brazilian Journal of Biological Sciences, 2: 79-84.

Licht, F.O. (2009). "2009 World Ethanol Production Growth to Hit FiveYear Low." World Ethanol \& Biofuels Report."

Maggio, A.; Reddy, M. P. and Joly R. J. (2000). Leaf gas exchange and solute accumulation in the halophyte Salvadora persica grown at moderate salinity. Environ. Exp. Bot. 44: 31-38.

Mazumdar, B.C. and Majumder, K. (2003). Methods of Physiochemical Analysis of Fruits. Daya Publishing House Delhi, India. 
Najafian, S.; Khoshkhui M.; Tavallali V. and Saharkhiz M.J. (2009). Effect of salicylic acid and salinity in thyme (Thymus Vulgaris L.): Investigation on changes in gas exchange, water relations, and membrane stabilization and biomass accumulation. Aust. J. Basic. Applied Sci., 3: 2620-2626.

Niu, G., D. Rodriguez, J. Mendoza, M. Jifon and G. Ganjegunte, (2012). Responses of Jatropha curcas to Salt and Drought Stresses. International Journal of Agronomy, Vol. 2012. Article ID 632026, 1 - 7 .

Pandey, V.C.; Singh, K.; Singh, J.S.; Kumar, A.; Singh, B. and Singh, R.P. (2012). Jatropha curcas: A Potential Biofuel Plant for Sustainable Environmental Development. Renewable and Sustainable Energy Reviews, 16: 2870-2883.

Parida, A.K.; Veerabathini, S.K.; Kumari, A. and Agarwal, P.K. (2016). Physiological, Anatomical and Metabolic Implications of Salt Tolerance in the Halophyte Salvadora persica under Hydroponic Culture Condition. Front Plant Sci. Article 7: 1-18.

Pérez-Harguindeguy N., Díaz S., Garnier E., et al. (2013). New handbook for standardised measurement of plant functional traits worldwide. Australian Journal of Botany, 61, 167-234.

Saleh, B. (2012). Salt stress alters physiological indicators in cotton (Gossypium hirsutum L.). Soil Environ. 31(2): 113-118.
Shibghatallah1, M. A. H.; Khotimah, S.N.; Suhandono, S.; Viridil,S., and Kesuma,T.(2013). Measuring Leaf Chlorophyll Concentration from Its Color: A Way in Monitoring Environment Change to Plantations", physics. bio-ph 2: 1305.1148.

Shraiy, A.M.E. and Hegazi, A.M. (2009). Effect of acetylsalicylic acid, indole-3-bytric acid and gibberellic acid on plant growth and yield of pea (Pisum Sativum L.). Aust. J. Basic Appl. Sci., 3: 3514-3523.

Tewfik, S.R.; Hawash, S.I.; Atteya, N. K.; Diwani G. I. and Farag, I.H. (2012). Techno-economic Appraisal of Biodiesel from Jatropha curcas: An Egyptian Case Study. Journal of Agricultural Science and Technology 2: 287-297.

Villar-Salvador, P.; Puértolas, J.; Cuesta, B.; Peñuelas, J.L.; Uscola, M.; Heredia-Guerrero, N. and Rey Benayas, J.M. (2012). Increase in size and nitrogen concentration enhances seedling survival in Mediterranean plantations. Insights from an ecophysiological conceptual model of plant survival. New For 43:755 -770.

War, A.R; Paulraj, M.G.; War, M.Y. and Ignacimuthu S. (2011). Role of salicylic acid in induction of plant defense system in chickpea (Cicer arietinum L.) Plant Signaling \& Behavior 6:11, 1787-1792. 
تأثير الاضافة الخارجية لحض السالسيلك علي الخصائص المورفولوجية والكيميائية لنبات

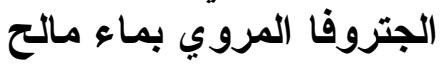

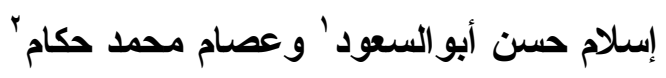

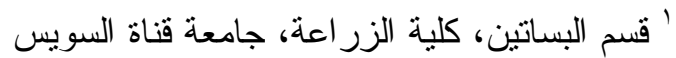

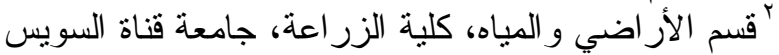

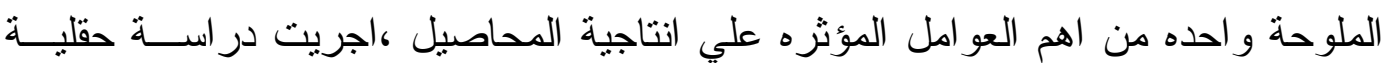

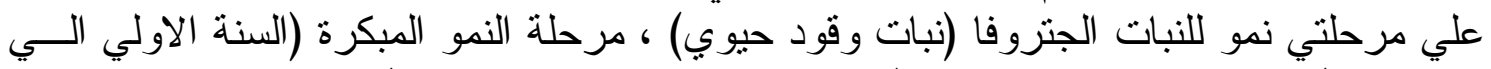

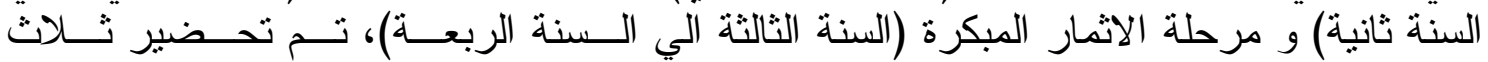

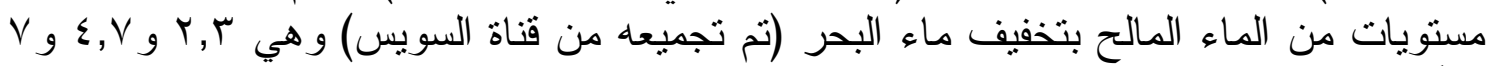

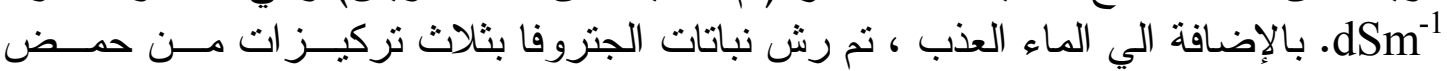

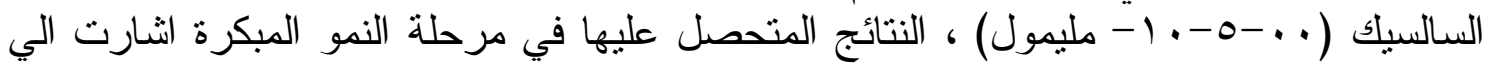

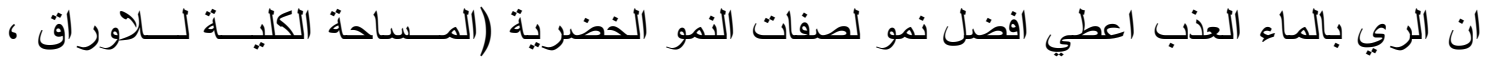

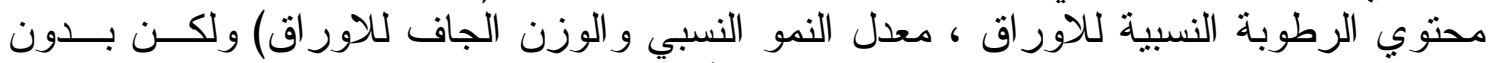

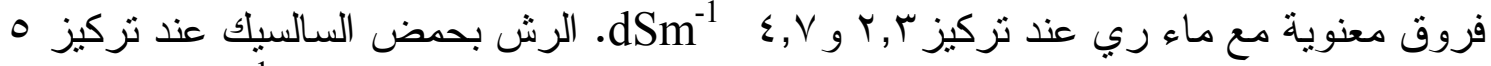

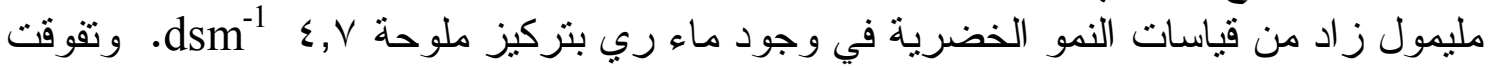

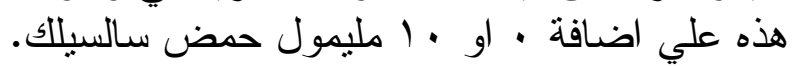

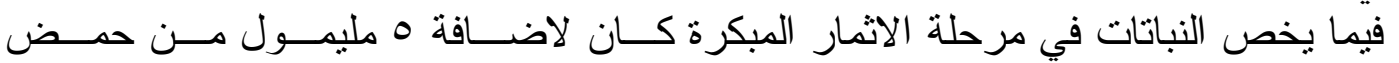

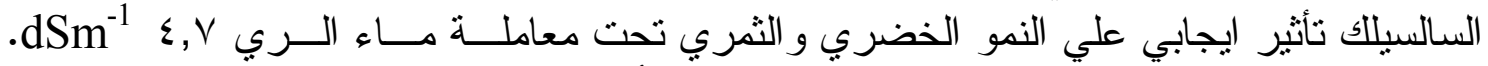

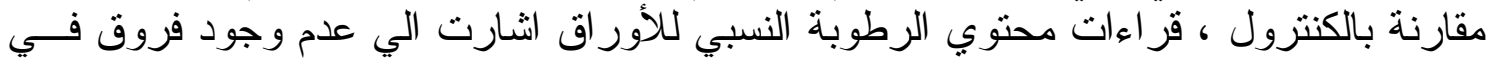

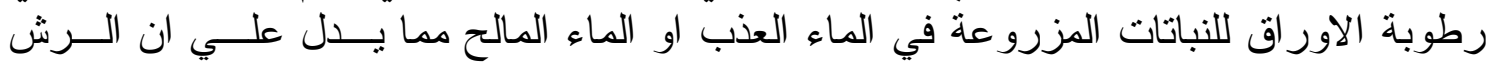

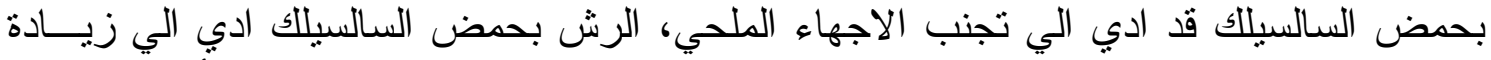

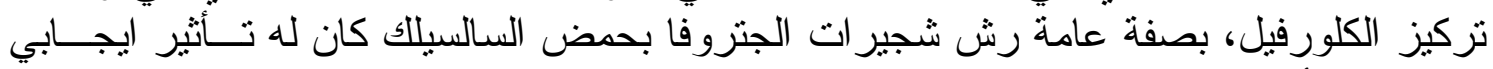
في تقليل التأثير السلبي للماء المالح. 